食道異物卜，鑑别診斷国濰ナル或場合等二用と テ甚ダ有用ナラント思考ス。

\section{Tracheopathia osteoplastica}

(Aschoff) 城所信五郎(整寀)

Tracheopathia osteoplastica ガ稀二ミル疾 喼デアルコト八抄録二述ベテ置イタ通りデア ル。称 $=$ 本邦二坽テ八其報告 7 检出シ得ナイ。 㭧者八 57 歲/男。約 2 ケ月前 $コ$ リ始マツタ器 下障碍が主訴デアル。「バリウム柕ニヨル「レ」

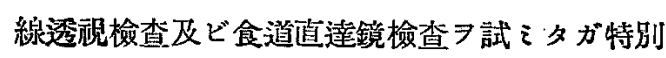
，所見ハ得ラレナ1 喉頭並二氣管”「レ線寫

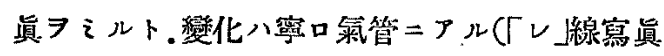
供筧)。氮管二於分ル凹凹不平，陰影ガ夫レデア ル。ソコデ喉頭並＝氣管直達鏡檢楂

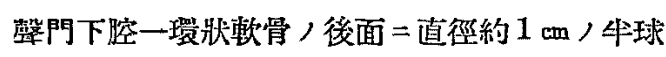
狀/蒼白: 青赤色, 比較的境界, 鮮明ナル嗹湟 ガミェル。潰瘍. 势其他ノ變化ハナ1。之ョリ 氣管全長二亘り（但シ氣管膜樣部フ除ク）壁八

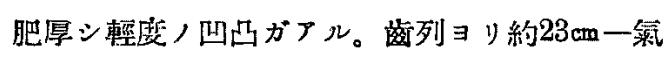
管枝分岐部前二於テ氣管，前及ビ右方二前述卜

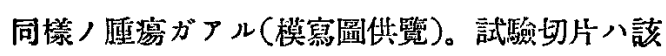
腫湯敦レモ極メテ硬り (Knochenhart) 㳯ウジ テ其一部ョ得タ。出血性デハナィ

組織學的所見 $(H-E$ 染色 $)$ : 異常二登灆シタ 上皮細胞下，結縞組織/中二絬締組織カラ軟骨 乃至骨二發韭シテ行ク各階榎がミラレル。

1. 極メテ密ニシテ且ツ多数, 核 篦。

2. 所謂“maskiertes Bindegewebe” 卜見 ルベキ裂。之八恐ラク軟骨化セントスルモ ノデアラり。

3、軟骨岛一之ヨ形成スル軟骨縕胞八大サ. 形態共二多種多樣デ，一部八既=石灰化シ
堹骨墖フ形成シテキル。然シ骨形成乃至骨

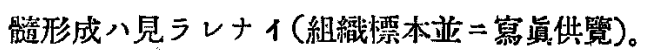

\section{2. 臨带運動ノ描曷二就テ}

(演)卢村親一郎(器志)

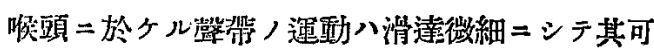
動方向玉單二内外轉二止アラズ前後，上下運動 玉隨件シ，其複雜ナル伸轉八立體的ニアルモ，

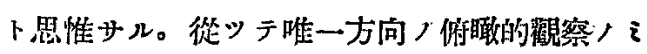

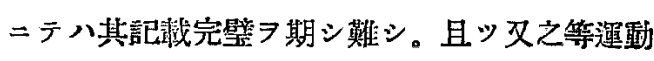
，「テンボ」相當速カニシテ其僢間ヨ目謷シタ

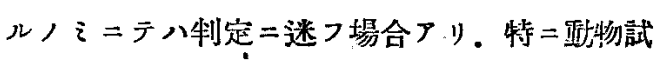
驗ニアリテハ意ノ如クナラズ. 同條件ラ以テ再 試任難キコトアッ。余等八之等，經驗二徽シ生

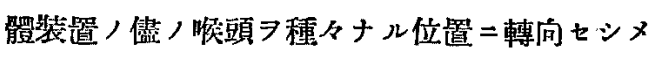

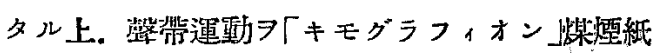
上二描寫セシムルコト二努メタリ。此實驗八㴔 順ナル成熟犬フ以テ喉頭部 7 露出。上下喉頭种

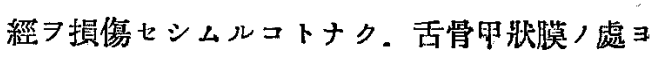
り離斷シ媣部咽頭。食道ノ一部习附着七ルア、 之ヨ起シ(凡ソ $45^{\circ}$ ) 左右甲狀軟骨板 7 左右對称 二適當セル錻子ラ以テ充分二固定セシム。

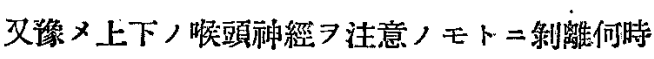
ニテモ槯二臨え簡單二切除シ得儿樣準储シオキ

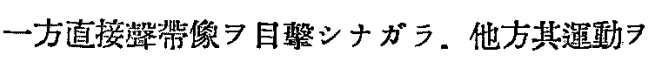
描寫シ之ト相對照シタリ。最初ハ描寫二直接描

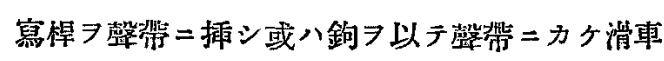
程ノ媒ニョリテ「キモグラフ」二其他端习接触 セシムル方法 $尹$ 取リタリ。然レドモ之等二依ル

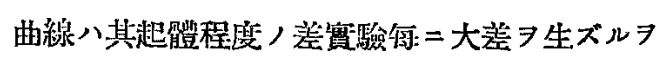
以テ其後八整帶

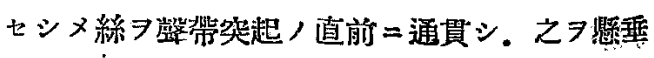
シ重量 附シ左右．上下．等後運動 總テ上下 
/運動ニナシテ满寫セシメタリ。郎チ上下運動 八體习固定辜ト共二轉倒セシメ，前後運動八喉 頭ヨ少シク元位 $ヨ$ 側方 $=$ 前部 $\ni$ 移シ，又左右 運動ハ一側馨帶. 假謷帶 7 除去シテ體 7 固定要 ト共二横轉セシメ。上述ノ装置「キモグラフ」 圆筒二適合セシメタリ。斯タシテ充分二其位趋 ニテ甲狀軟骨 固定シタル後二記载シタリ。以

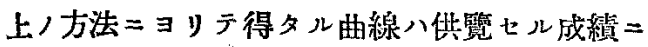
シテ大體次! 成績 $フ$ 得タリ。

（1）左右開閉運動（第 1 圆及ビ第 2 圖）

a) 自然發韾ヨナサシメ神經枝习遂次切斷シ 行ク二其閉鎖二最モ與へルモノ八側筋ナルヨ知 s。

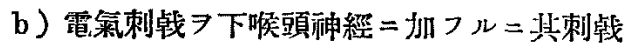
ノ强弱ニョリテ開閉異ナラズ. 唯其程度ヨ異二 スルノテデアル。(第 2 圖[1])

II) 前挠運動 (第 3 圖[上])

a) 此動キ八友右上喉頭神經運動枝電粙刺钱 ニョリテ現ハルコト著明(第 3 圖[1])

b) 此動キ八左右共同ナルヨ以テ一側／該神 經フ淂除スルョリモ爾側/切斷ニ由ツテ初メテ 影響习蒙ルコト大ニシテ殆ンド消失スルニ至ル (第 3 圖[2])。

III) 上下運郵(第 3 圖[下]及ビ第 4 圖)

a）此動キ八殆ント5知頭神經＝關係七ズ之 フ切斷スルモ影響シ見ズ(第 4 圖[1])

b) 此動キ八側筋 /作用大ニシテ若シ此䃼縒 枝习切斷七バ甚ダ微弱トナル(第4 圖[2．3]）

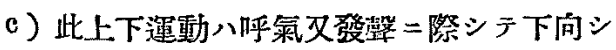
吸氯二上间スルモノニシテ余等ノ描寫ニヨレバ

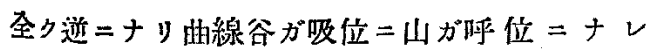

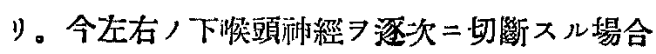
多ク！試獸ニアリテハ呼吸困難. 㗪鳴

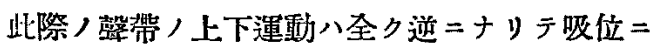
山トナり呼位二谷）位置 7 取ルニ到ル（第 4 圖 [3])。若シ此際呼吸困難 $习$ 除ク篇 $メ=$ 氣管切開 ヨ行へバ聲㕩ハ不動トナリテ直線二現ハル（第 3 圖[3])。郎チ此呼吸困難=於ケル際 /上下㞄

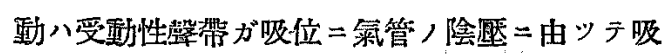
ハル、モノト思惟サル。

23. 缺 席

\section{4. フォン. メッカー氏無端消息子} ニテ治癒セシメシ酒痕性食道狭

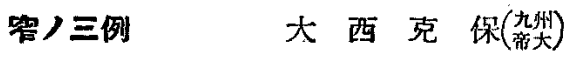
九大耳鼻咽啖科二於テ最近 2 ケ年間 $=3$ 例， 高度，洀痕食道诙窄㭧省。郎チ1，23年前水醋 酸 7 誤紫七シ 27 歲男子。2.2 年前自殺, 目的 $=$ 工業用監酸鮎下， 31 歲男子。3.95月前自

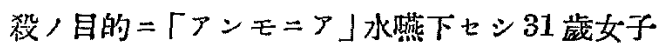

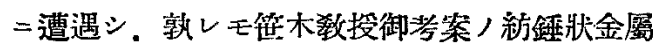
球ヨ用七コ、ン.八っカ一氏無端消息子法二ヨ リ治癒セシメタリ。

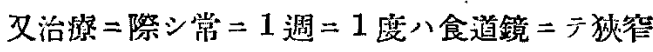
狀態 香視シ。本法ノ長所トシテハ胃瘦こヨリ

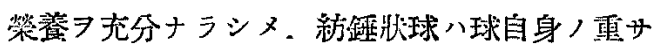

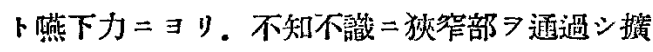
張力温和 =シデ粘膜モ損傷セズ 又舁者自ラ隨

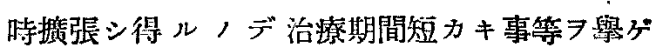
得。胃瘦八狄窄，再發七ザルヨ確カメ閒鎖スべ キナリ。

25 . 缺 席

閉 會—午後五時十五分 